\title{
TOURISM ASSETS MANAGEMENT STRATEGY IN ROTE NDAO DISTRICT - NUSA TENGGARA TIMUR
}

\section{Cicilia Apriliana Tungga, Olivia Louise Eunike Tomasowa}

Nusa Cendana University, Indonesia

E-mail: cicilia.tungga@staf.undana.ac.id, olivia.tomasowa@staf.undana.ac.id

\begin{tabular}{|c|c|}
\hline ARTICLE INFO & ABSTRACT \\
\hline $\begin{array}{l}\text { Received: } \\
\text { November, 26 } \\
2021 \\
\text { Revised: } \\
\text { December, 17th } \\
2021 \\
\text { Approved: } \\
\text { December, 19th } \\
2021\end{array}$ & $\begin{array}{l}\text { Ndao Regency is one of the regencies that prioritizes the } \\
\text { direction of development for } 2019-2024 \text { in the tourism } \\
\text { sector. The problem in Rote Ndao District is the absence of } \\
\text { asset management that focuses on potential tourism } \\
\text { assets. In this study, the formulation of the problem is to } \\
\text { place a tourism asset management strategy in Rote Ndao } \\
\text { Regency. The purpose of this study is to evaluate, identify } \\
\text { and describe the management of regional assets. This } \\
\text { study also formulates priority strategies to improve local } \\
\text { asset management of the Rote Ndao District Government. } \\
\text { The data consisted of primary and secondary data. } \\
\text { Primary data were obtained from direct observation, } \\
\text { interviews and questionnaires using purposive sampling } \\
\text { method. While secondary data obtained from literature } \\
\text { and documents relevant to the research. The analysis in } \\
\text { this study uses a SWOT analysis. The results of the study } \\
\text { indicate that the weak competence of human resources in } \\
\text { asset management is due to the lack of guidance, } \\
\text { supervision, lack of supporting facilities and infrastructure } \\
\text { and the lack of cooperation involving the private sector } \\
\text { and the community to develop tourism potential. The } \\
\text { control system affects the performance of regional asset } \\
\text { management. The prioritized strategy is to improve the } \\
\text { quality of human resources in managing and reporting } \\
\text { local government assets. }\end{array}$ \\
\hline
\end{tabular}

Cicilia Apriliana Tungga, Olivia Louise Eunike Tomasowa (2021).

Tourism Assets Management Strategy in Rote Ndao District Nusa Tenggara Timur. Journal Eduvest. 1(12): 1499-1506

How to cite:

E-ISSN:

Published by: $\quad$ https://greenpublisher.id/ 
Cicilia Apriliana Tungga, Olivia Louise Eunike Tomasowa

\begin{tabular}{ll}
\hline KEYWORDS & Strategy, Tourism Asset Management, SWOT Analysis \\
\hline (C) (1) (?) & $\begin{array}{l}\text { This work is licensed under a Creative Commons } \\
\text { Attribution-ShareAlike 4.0 International }\end{array}$ \\
\hline
\end{tabular}

\section{INTRODUCTION}

Since the implementation of regional autonomy, the maximum authority has been given to regional governments to manage the wealth owned by the regions (Siregar et al., 2020). Local governments are required to be professional, transparent, accountable, efficient and effective in managing regional wealth (Pamungkas et al., 2018). Local governments need to have a reliable management system to support the management of regional assets, starting from the planning, implementation/management and monitoring systems (Sulistyaningsih et al., 2021). It is necessary to have indicators and performance standards owned by local governments in managing regional assets or assets.

Assets need to be managed effectively and efficiently in order to minimize costs, generate maximum profits, and optimize the use and utilization of the assets concerned (Slamet \& Fadjarwati, 2020). According to Siregar (2004:561), the implication of the use and management of assets that are not optimal is not obtaining a beneficial value that is balanced with the intrinsic value and potential contained in the asset itself (Fusco Girard \& Vecco, 2021).

One of the strongest sectors in increasing Regional Original Income (PAD) is the tourism sector. Tourism has played an important role in advancing the economy of many regions (Dunets et al., 2019). According to Bagit, et al, progress and prosperity are getting higher and have made tourism a basic part of human needs or lifestyle and have moved millions of people to get to know nature and culture to other areas of the world (Grima et al., 2020).

Rote Ndao is one of the districts that are responding to the challenges of regional autonomy. With so many cultural and natural resources, Rote Ndao Regency prioritizes the direction of development for 2019-2024 in the tourism sector. This is stated in the vision of Rote Ndao Regency for the 2019-2024 Period: "The realization of a dignified Rote Ndao community in a sustainable manner relies on tourism supported by agriculture and fisheries". The Department of Culture and Tourism as the technical service responsible for this matter needs to strengthen and improve its performance through various programs and supporting activities (Phillips, Thai, \& Halim, 2019). This is reasonable because tourism plays an increasingly important role. This industry can make an increasingly significant contribution to domestic economic growth and to improve people's welfare, as well as having primary mover and multiple effect capabilities with its multi-dimensional nature (Dung \& Thanh, 2021).

Rote Ndao Regency has a number of potential tourism assets that can be relied upon, but most of them have not been fully exploited (Djahimo \& Bora, 2019). There are many obstacles encountered, for example, most of the tourist areas are not easily accessible with access to transportation and the location of tourist objects whose locations are unknown to tourists, road access that still needs to be improved, and the availability of facilities and infrastructure that support tourist objects (Mamirkulova et al., 2020). With the policy that regulates the management of tourism assets, it is hoped that the number of tourists visiting Rote Ndao Regency will continue to increase (Pello \& Pekuwali, n.d.).

The priority of this research is to evaluate the system and policy of tourism asset management in Rote Ndao Regency (Atmaji \& Qodir, 2021). Research on the evaluation and policy of tourism assets is considered very important because it will have an impact 
on increasing the Regional Original Income (PAD) of Rote Ndao Regency.

Rote Ndao Regency has considerable potential in the tourism sector, so it needs to be optimized properly. In optimizing all existing potentials, it takes a great commitment from all stakeholders, including local governments. The Regional Government of Rote Ndao Regency has high potential and opportunities to conserve and optimally manage every existing tourism asset so that it can have a positive impact on PAD and especially for the welfare of the community. So the purpose of this study is to examine how the strategies taken by the local government in managing tourism assets in Rote Ndao Regency.

\section{RESEARCH METHOD}

The types of data used in this research are quantitative and qualitative data. Quantitative data are the number of tourist visits and the number of tourism assets in Rote Ndao, while qualitative data are the types of tourism assets, policies and other information relevant to this research.

Sources of data in this study in the form of primary data and secondary data. The primary data used in this study were obtained through observation, questionnaires and interviews. For secondary data that is quantitative, namely data in the form of numbers. Data sources are obtained from official government publications such as the Central Statistics Agency (BPS), the Tourism Office and from other relevant sources.

The data analysis technique used to answer the objectives of this research is SWOT analysis to formulate tourism asset management policies. SWOT analysis stands for Strengths (strengths), Weaknesses (weaknesses), Opportunities (opportunities) and Threats (threats) in the environment faced by the region. The SWOT stage assumes that an effective strategy is to maximize strengths and opportunities and minimize weaknesses and threats. External factors and internal factors form the SWOT matrix.

\section{RESULT AND DISCUSSION}

\section{Tourism Asset Management Strategy in Rote Ndao Regency - East Nusa Tenggara}

SWOT analysis is used to identify the influence of internal factors, strengths, weaknesses and external factors, opportunities and obstacles in optimizing the management of regional tourism assets in Rote Ndao Regency. Overall, several regional assets in Rote Ndao Regency have not been utilized optimally, resulting in the low contribution of revenue from the use of regional assets to Regional Original Income. This also shows the low level of regional fiscal independence in managing and optimizing various asset resources owned. Regional assets are an important resource in supporting Regional Original Income (PAD).

The following are the results of identification through SWOT, several factors that influence the optimization of regional asset management in Rote Ndao Regency. 


\section{Cicilia Apriliana Tungga, Olivia Louise Eunike Tomasowa}

Table 1 Identification of Internal Factors SWOT Analysis

\begin{tabular}{|l|l|l|l|}
\hline Internal factors & Weight & Rating & Score \\
\hline Strength Regulations & 0,15 & 2 & 0,28 \\
\hline $\begin{array}{l}\text { Availability of Regional } \\
\text { regarding regional income and financial and } \\
\text { asset management }\end{array}$ & 0,06 & 1 & 0,08 \\
\hline Private participation in asset management & 0,10 & 2 & 0,17 \\
\hline $\begin{array}{l}\text { Political Will from the leadership in the } \\
\text { management of regional assets }\end{array}$ & & & 0,53 \\
\hline Total & Weight & Rating & Score \\
\hline Weakness & 0,08 & 2 & 0,15 \\
\hline $\begin{array}{l}\text { Inadequate quality and quantity of human } \\
\text { resources }\end{array}$ & 0,08 & 1 & 0,09 \\
\hline $\begin{array}{l}\text { Rarely attend functional training in regional } \\
\text { asset management }\end{array}$ & 0,08 & 1 & 0,09 \\
\hline $\begin{array}{l}\text { Facilities and infrastructure are not in } \\
\text { accordance with the minimum service } \\
\text { standards that have been determined }\end{array}$ & 0,08 & 2 & 0,14 \\
\hline $\begin{array}{l}\text { Rewards and Punishments have not been } \\
\text { adjusted to actual conditions based on } \\
\text { performance }\end{array}$ & 0,09 & 1 & 0,13 \\
\hline Asset management fund which is still limited & 0,09 & 0,16 \\
\hline $\begin{array}{l}\text { Asset management regulations that are not } \\
\text { yet comprehensive }\end{array}$ & 0,09 & 2 & 0,56 \\
\hline \multicolumn{1}{|l}{ Total } & & \\
\hline
\end{tabular}

Source : Data processed (2021)

Berdasarkan analisis faktor internal, faktor kekuatan pentingnya Peraturan Daerah mengenai pendapatan dan pengelolaan keuangan dan aset daerah menjadi prioritas utama yang diperlukan dalam upaya optimalisasi pengelolaan aset daerah. Perangkat hukum menjadi modal utama bagi Pemerintah Daerah dalam menjalankan optimalisasi pengelolaan aset secara lebih berdaya guna. Produk hukum yang selama ini mengatur dalam pengelolaan aset daerah adalah antara lain Peraturan Pemerintah Nomor 28 Tahun 2020 tentang Pengelolaan Barang Milik Negara/Daerah dan Peraturan Menteri Dalam Negeri Nomor 19 Tahun 2016 tentang Pedoman Teknis Pengelolaan Barang Milik Daerah.

Kelemahan yang harus diprioritaskan untuk ditangani adalah pentingnya Peraturan Daerah yang mengatur pengelolaan aset secara lebih komprehensif dengan skor 0,16. Di Kabupaten Rote Ndao, hingga saat ini belum memiliki produk hukum berupa Peraturan Daerah yang mengatur mengenai inventarisasi dan pengelolaan aset daerah. Dasar hukum yang selama ini digunakan dalam pengelolaan aset daerah adalah Peraturan Pemerintah Nomor 28 Tahun 2020 tentang Pengelolaan Barang Milik Negara/Daerah dan Peraturan Menteri Dalam Negeri Nomor 19 Tahun 2016 tentang Pedoman Teknis Pengelolaan Barang Milik Daerah dan belum ada produk Peraturan Daerah yang secara khusus mengatur pengelolaan aset daerah, sehingga hal ini menyebabkan kurang optimalnya pemanfaatan aset sesuai dengan kemampuan daerah. Kelemahan yang kedua tentang SDM yang belum memadai dalam Pengelolaan Aset Daerah dengan skor 0,15.

Tabel 2 Identifikasi Faktor Eksternal Analisis SWOT

Eksternal factors 


\begin{tabular}{|l|l|l|l|}
\hline Opportunity & Weight & Rating & Score \\
\hline Increased regional activity centers & 0,15 & 1 & 0,19 \\
\hline Increased regional economic growth & 0,18 & 2 & 0,29 \\
\hline $\begin{array}{l}\text { The potential for taxpayers and levies to experience } \\
\text { a positive increase in tax effort }\end{array}$ & 0,16 & 1 & 0,24 \\
$\begin{array}{l}\text { The dynamics of regional, national and } \\
\text { international environmental changes }\end{array}$ & 0,12 & 1 & 0,14 \\
\hline Total & & & 0,86 \\
\hline Threats Weight & Rating & Score \\
\hline $\begin{array}{l}\text { Changes in regulations quickly so that the } \\
\text { management administration is not in accordance } \\
\text { with existing conditions }\end{array}$ & 0,14 & 1 & 0,18 \\
\hline Investment Risk & 0,13 & 2 & 0,21 \\
\hline Total & & &, 49 \\
\hline
\end{tabular}

Source : Data processed (2021)

Meanwhile, from the external side, the first priority opportunity is the increasing regional economic growth, which is an opportunity for the Regional Government to further optimize regional assets that can provide high economic and even socio-cultural values. Based on Government Regulation of the Republic of Indonesia Number 28 of 2020 concerning Management of State/Regional Property and Minister of Home Affairs Regulation Number 19 of 2016 concerning Technical Guidelines for Management of Regional Property, utilization is the utilization of regional property that is not used in accordance with the main tasks and functions of the Work Unit. Regional Apparatuses (SKPD) in the form of lease, borrow and use, cooperation in utilization, build for handover and build for handover without changing ownership status (Rahmat \& Rutinaias, 2020).

In connection with the utilization of regional assets, especially fixed assets such as land or buildings/buildings that have not been utilized optimally even though they can provide added value, value in use and are able to increase the economic value of the assets concerned, it can be implemented through the use of business, namely the utilization of regional assets, especially tourism assets. in Rote Ndao County.

However, the high investment risk becomes an obstacle in managing regional assets. Therefore, it is necessary to have a policy that provides a conducive climate for the development of regional investment, especially in the provision of adequate supporting infrastructure and a more efficient bureaucratic system (Windhyastiti, Hidayatullah, \& Khouroh, 2019). The results of the SWOT analysis show that the combination of internal and external factors is in the quadrant III matrix position with an internal factor value of 0.02 and an external factor of 0.19 which means that a defensive strategy is required. In this position, regional asset management faces great external opportunities but internal resources are still weak. This is due to not being able to take advantage of these opportunities optimally. So the focus of defensive strategies in a position like this is to minimize internal constraints so that they can respond and take better advantage of external opportunities.

Asset Management Strategy in Rote Ndao Regency with a defensive strategy of internal resource weakness in capturing opportunities for economic dynamics. Efforts to optimize the management of Tourism Assets in Rote Ndao Regency must be supported by ability, high expertise and supportive behavior. Tourism asset management strategies 


\section{Cicilia Apriliana Tungga, Olivia Louise Eunike Tomasowa}

include:

a. Identify and inventory the value and potential of Regional Tourism Assets. In this case, the local government needs to know the amount and value of its regional assets, both those currently controlled and those that have not been controlled. Identification and inventory activities are intended to obtain accurate, complete and up-to-date information regarding regional assets owned or controlled by regional governments. Identification and inventory of these regional assets is important for the preparation of the Regional Wealth Balance which will be reported to the public

b. The importance of regional asset management information systems. To support efficient and effective management of regional assets and create transparency of regional asset management policies, local governments need to have or develop a comprehensive and reliable management information system as a tool for decision making. The regional asset management information system also contains a database of assets owned by the region. The system is useful for generating accountability reports.

c. Supervision and control of the utilization of tourism assets. To improve the supervisory function, the role of internal auditors is very important.

d. Improving the professionalism of human resources in the field of asset management and regional finance.

e. Institutional structure and resources of asset managers. All bureaucratic apparatus related to asset management must have responsibilities within the limits of their authority so that the distributed assets remain under control, either through coordination mechanisms or consolidation mechanisms.

f. Creating systems and mechanisms for managing regional assets/goods that are integrated, efficient, effective and have clear authority and authority.

g. Exploring and assessing the potential and allocation of assets that can be collaborated with investors as a source of regional income so that in the long term regional finances have financial independence that does not always have to depend on taxes, levies, or balancing funds.

Support improvement of management and business capabilities for institutions that control and manage regional assets in an effort to optimize existing benefits and potentials, especially in the context of empowering BUMD and collaborated assets.

\section{CONCLUSION}

Assets are an important resource for local governments. By managing regional assets properly and adequately, local governments will obtain sources of funds to finance development in the regions. In managing regional assets, regional governments must pay attention to planning needs and budgeting, procurement, receipt, storage and distribution, use, administration, utilization, security and maintenance, assessment, elimination, transfer, guidance, supervision and control, financing and claims for compensation.

All of these activities are important aspects of regional asset management. A defensive strategy due to weak internal resources in capturing the dynamics of regional development, optimizing regional asset management through increasing the availability of supporting infrastructure and developing adequate human resources and the importance of establishing partnerships with third parties are options for the Rote Ndao Regency Government for further asset management planning. 
The related service units or SKPDs play an important role in managing the assets of Rote Ndao Regency. This is because most of the assets or assets of the region are in the relevant service units according to their respective functions and roles with different designations. Efforts to improve the professionalism of human resources in the field of asset management and regional finance are very important in order to support the improvement of management and business capabilities for institutions that control and manage regional assets and optimize existing benefits and potentials, especially in the context of empowering BUMD and assets that are collaborated.

\section{REFERENCES}

Atmaji, Dwi, \& Qodir, Zuly. (2021). Policy Implementation To Improve Tourism Destination Based On Local Wisdom In Gunungkidul District. International Journal on Recent Trends in Business and Tourism (IJRTBT), 5(3), 1-11.

Djahimo, Santri E. P., \& Bora, Dewi I. N. Bili. (2019). Language And Attitude: A Review And Reflection On Tourism And Hospitality In NTT Province, Indonesia.

Dunets, Alexandr Nikolaevich, Vakhrushev, Igor Borisovich, Sukhova, Maria Gennadievna, Sokolov, Maxim Sergeevich, Utkina, Kseniya Mihajlovna, \& Shichiyakh, Rustem Adamovich. (2019). Selection of strategic priorities for sustainable development of tourism in a mountain region: concentration of tourist infrastructure or nature-oriented tourism. Entrepreneurship and Sustainability Issues, 7(2), 1217.

Dung, Hoang Phuong, \& Thanh, To Trung. (2021). Economic complexity and shadow economy: A multi-dimensional analysis. Economic Analysis and Policy, 72, 408422.

Fusco Girard, Luigi, \& Vecco, Marilena. (2021). The "Intrinsic Value" of Cultural Heritage as Driver for Circular Human-Centered Adaptive Reuse. Sustainability, 13(6), 3231.

Grima, Nelson, Corcoran, Will, Hill-James, Corinne, Langton, Benjamin, Sommer, Haley, \& Fisher, Brendan. (2020). The importance of urban natural areas and urban ecosystem services during the COVID-19 pandemic. PloS One, 15(12), e0243344.

Mamirkulova, Gulnara, Mi, Jianing, Abbas, Jaffar, Mahmood, Shahid, Mubeen, Riaqa, \& Ziapour, Arash. (2020). New Silk Road infrastructure opportunities in developing tourism environment for residents better quality of life. Global Ecology and Conservation, 24, e01194.

Pamungkas, Bambang, Flassy, D. A., Yudanto, Sugiharto, Rachman, Hari Amirullah, Rahayu, Setya, Komarudin, Sugiharto, \& Setijono, Hari. (2018). Accrual-based accounting implementation in Indonesian's local governments compared to other countries' experiences. Man in India, 98(1), 1-23.

Pello, Jimmy, \& Pekuwali, Umbu Lily. (n.d.). The Community Support For The Enforcement Of Sandalwood (Cendana)'S Regional Regulation: A Sustainability Intensification Of Cendana Management In East Nusa Tenggara Province, Indonesia.

Phillips, Schavana, Thai, Vinh V, \& Halim, Zaheed. (2019). Airline value chain capabilities and CSR performance: the connection between CSR leadership and CSR culture with CSR performance, customer satisfaction and financial performance. The Asian Journal of Shipping and Logistics, 35(1), 30-40.

Rahmat, Yuliansyah, \& Rutinaias, Haholongan. (2020). Fixed Assets Analysis and Its Inventory of Management and Use of Assets in the Government of East Jakarta City 


\section{Cicilia Apriliana Tungga, Olivia Louise Eunike Tomasowa}

2013-2016. Advances in Economics, Business and Management Research, 127, $162-168$

Siregar, Robert Tua, Sinaga, Rudi Salam, Nasution, Ilham Ramadhan, Nasution, Chairika, Panjaitan, Ferry, \& Modifa, Ira. (2020). Regional Development Environment: Implementation, Realization \& Contribution of Revenue in Pematangsiantar. IOP Conference Series: Earth and Environmental Science, 469(1), 12052. IOP Publishing.

Slamet, Fadila Febianisa, \& Fadjarwati, Nurlaila. (2020). Evaluasi kinerja aset fasilitas wisata domba di Kabupaten Garut. Jurnal Manajemen Aset Infrastruktur \& Fasilitas, 4(3).

Sulistyaningsih, Tri, Nurmandi, Achmad, Salahudin, Salahudin, Roziqin, Ali, Kamil, Muhammad, Sihidi, Iradhad T., Romadhan, Ach, \& Loilatu, Mohammad Jafar. (2021). Public Policy Analysis on Watershed Governance in Indonesia. Sustainability, 13(12), 6615.

Windhyastiti, Irany, Hidayatullah, Syarif, \& Khouroh, Umu. (2019). How to increase city investment attraction. International Journal of Scientific and Technology Research, 8(9), 1070-1073. 